\title{
Astronomy across cultures: reporting experiences on the GalileoMobile education activities in the Paiter Suruí indigenous community
}

\author{
Patrícia Figueiró Spinelli1,1, Ana Paula Germano, ${ }^{1,2}$, Cristina Fernades ${ }^{3}$, Sandra Benitez- \\ Herrera $^{1}$, Felipe Carrelli Sá Silva ${ }^{4}$ and GalileoMobile team \\ ${ }^{1}$ Museu de Astronomia e Ciências Afins, Coordenação de Educação em Ciências, Rua General Bruce \\ 586, Rio de Janeiro, Brazil \\ ${ }^{2}$ Universidade Federal Fluminense, Rua Tiradentes, 148, Niterói, Brazil \\ ${ }^{3}$ Observatório Nacional, Rua General José Cristino 77, Rio de Janeiro, Brazil \\ ${ }^{4}$ Independent film-maker, Rio de Janeiro, Brazil
}

\begin{abstract}
This work is the report of an astronomy non-formal education expedition carried out by the GalileoMobile initiative in the Paiter Suruí indigenous communities, in the Brazilian Amazon, that took place in November 2016. This ethnic group remained "officially uncontacted" by non-natives until the late 1960 's, when the population dropped significantly and they faced deep changes in their way of living and traditions. Nowadays, the Paiter Suruí are seeking ways to maintain their cultural identity and land. Thus, differently from previous GalileoMobile itinerant projects, which had the goal of bringing modern astronomy closer to youngsters of regions with scarce access to science outreach actions, this particular expedition had the goal of establishing an exchange of knowledge related to astronomy, promoting a dialogue with the members of this group to understand and record their relationship with the sky. The ground team, comprised of three astronomers, one filmmaker and one anthropologist, undertook the study of various academic works on ethno and cultural astronomy, as well as specific texts on science education in traditional communities and ethnography of Brazilian indigenous peoples. During the expedition, interviews with the Paiter Suruí elders were held, having as a starting point astronomy outreach activities such as the sky observation with telescopes. We were able to collect three myths related to the Sun, Moon and rainbow. The result of activities, interviews and transcripts were recorded in a series of videos that will be returned to the community, so that they can be used in schools and community centres as educational material for the preservation of the Paiter Suruí culture, as well as a resource for a detailed ethnographic study of their astronomy.
\end{abstract}

${ }^{1}$ Corresponding author: patriciaspinelli@mast.br 


\section{INTRODUCTION}

GalileoMobile (http://www.galileo-mobile.org/) is a non-profit, itinerant, science education initiative that brings modern astronomy closer to young people around the world, with emphasis in regions that have little or no access to other outreach actions. The initiative was created in late 2008 inspired by the International Year of Astronomy 2009 (IYA2009) and is currently run by astronomers, educators, science communicators and one film-maker. Since its creation in 2008, the initiative has organised expeditions in Chile, Bolivia and Peru (2009); Bolivia (2012); India (2012); Uganda (2013); Bolivia and Brazil (2014); Colombia (2014); Argentina, Brazil, Chile, Colombia, Ecuador, Peru (2015); Brazil (2016) and Cyprus (2017), reaching nearly 20,000 students and teachers across the world. The goals of the GalileoMobile are:

- To visit schools and communities and organize astronomy hands-on sustainable activities, sky observations, and donate educational material;

- To provide schools and teachers with the tools and knowledge to run the activities independently, facilitating the sustainability through teacher workshops and community building;

- To encourage peace and mutual understanding by acknowledging, alongside modern scientific views, traditional knowledge related to astronomy and the cosmovision of the communities visited;

- To share the experiences with a wide audience through appropriate channels and resources in order to inspire initiatives with similar vision.

Building on the success of a pilot expedition in the Bolivian Amazon in 2012, GalileoMobile organised an extended itinerant project to the region in 2014, named BrazilBolivia (BraBo). For five weeks, GalileoMobile went to the Bolivian Department of Pando and the neighbouring Brazilian states of Acre and Rondônia. The team travelled 4,210 km visiting 22 institutions, among them several regular and two indigenous schools, as well as two institutions for visually impaired children. The final product of the expedition was a documentary movie entitled Light-Year (Ano-luz, original name) ${ }^{2}$. The idea of promoting astronomical activities with traditional groups was by our collaborator, Maria do Carmo Barcellos, an indigenist with decades of experience with the Paiter Suruí indigenous group of Cacoal, Brazil. In Barcellos' view, astronomy could represent an opportunity towards the maintenance of their cultural identity, because the elders, holders of traditional knowledge (that is only transmitted orally), were becoming too old and, consequently, the knowledge of the group was in risk of disappearing. In addition, in Brazil, in many non-isolated indigenous villages, there is a primary school that follows a regular school program and, thus, topics of modern science are also taught at these schools. However, the relationships between scientific and traditional knowledge is an absent debate.

A year after the GalileoMobile BraBo project took place, as part of the post-expedition commitments and the project's agenda for the International Year of Light and Light-based Technologies (IYL2015), the team was dedicated to disseminating the Light-Year documentary.

Through various media channels, social networks and public exhibitions, that were often accompanied by debates with its various audiences, the documentary received both

2 Available in: http://www.galileo-mobile.org/galileomobile-expeditions/galileomobilebrabo2014/galileomobile-documentary-brabo2014. 
positive and negative feedback. Special criticism was given to the attitudes and approach of the astronomers towards the Paiter Suruí members.

These critiques stimulated debates within GalileoMobile about the role of science education and outreach projects in traditional communities. The debate culminated with an ethnographic analysis of the Light-Year documentary presented during the I GalileoMobile Conference held at the Museum of Astronomy and Related Sciences (MAST) in Rio de Janeiro, in October 2016. Within this context, it was acknowledged by the GalileoMobile members the importance of having an expert in anthropology, advising the group, when working with indigenous or traditional peoples. In addition, a new model of activities for the GalileoMobile Constellation Rondonia project, that would return to the same indigenous communities, were planned following a thorough anthropological advice.

Part of the reflections and activities developed during our second visit to the Paiter Suruí, as well as a brief introduction of the characteristics of this ethnic group, are presented in the sections that follow.

\section{THE PAITER SURUI}

In Brazil, indigenous peoples comprise a large number of distinct ethnic groups, spread across the country, who have inhabited the land that now constitutes Brazil since prior to the Portuguese arrival (around 1500). Indigenous peoples are inheritors and practitioners of unique cultures. They interact with the environment and their society in ways that are considered distinct from the dominant society. According to the last Brazilian census, the current indigenous population is 896,900 .

The Paiter Suruí group of the Rondônia State call themselves Paiter, which means "the true people, we ourselves". They live in an indigenous land called Sete de Setembro, an intact piece of Amazon rainforest in the area located in the north of the municipality of Cacoal. The land is distributed in smaller villages called Linhas (lines), with population sizes ranging from forty to a hundred people in each village.

They speak Tupi-Mondé language and according to the website Povos Indigenas do Brasil $^{3}$ "despite the pressures that they have suffered from the non-Indians, (...) the Paiter Suruí still maintain many of their traditions, both those that have to do with material culture and with cosmological aspects". Since 1969, when the Paiter Suruí were "officially" contacted their relations with non-Indians have produced profound changes in their society.

\section{THEORETICAL BACKGROUND FOR THE OUTREACH ACTIVITIES IN TRADITIONAL COMMUNITIES}

Cultural astronomy or ethnoastronomy is concerned with learning and understanding the astronomical knowledge developed by different cultures and how this knowledge impacts the daily lives of traditional groups. In the case of the Paiter Suruí, there are few studies made in this field when compared with other Brazilian ethnic groups. One can mention various studies whose knowledge of the sky is widely documented, both by astronomers and by anthropologists, as is the case of the Tupi-Guarani linguistic trunk ethnicities, among them the Ticuna [1].

Among these systems of knowledge related to astronomy of Brazilian ethnic groups, it is possible to mention:

${ }^{3}$ Available in: https://pib.socioambiental.org/en/povo/surui-paiter. 
- The recognition of astronomical phenomena and their explanation through myths (such as the appearance of the Sun, Moon and the world, recognition and use of the phases of the Moon for agriculture);

- The orientation and recognition of the change of seasons by the presence or absence of stars in the sky and;

- The recognition of stars (which in some cases are planets) as announcers of diverse situations like war, death, drought, among others.

The (re)acknowledgement of this kind of knowledge by science outreach projects as GalileoMobile, increases the possibilities of exchange. In addition, ethnoastronomy can be an excellent tool for spreading science and education as a whole, since it is possible to recognize that the traditional knowledge, as ours, is elaborated through empiricism.

The most relevant academic works analysed by the ground team of GalileoMobile Constellation Rondônia project, before planning the activities for a second visit to the Paiter Suruí were:

- "Elephants in the room" where the public encounters "Science"?: A response to Darrin Durant, "Accounting for expertise: Wynne and the autonomy of the lay public" by Brian Wynne (2014) [2];

- Nós Paiter, os Suruí de Rondônia by Betty Mindlin (1985) [3];

- The Savage Mind by Claude Lèvi-Strauss (1962) [4];

- La escolarización en los pueblos indígenas americanos: impactos y desafios by Paladino and García (2011) [5].

In brief, these studies argued that science outreach is as old as science itself, however, only a few years ago has it been consolidated as an academic field of study. Although the nomenclature still remains open (sometimes being called Science Outreach or Science Education, Public Outreach or even Science Communication) it is a consensus that educators or facilitators of projects aiming at the dissemination of science need to consider many factors. Projects must pay special attention to their audiences, in order to avoid the risk of ethnocentrism [2] or adopting the information deficit model when communicating knowledge, since this may lead to public scepticism or hostility towards science and technology from non-experts.

Another very relevant aspect discussed in the context of GalileoMobile Constellation Rondônia 2016 project was that the way children learn is strongly shaped by culture, as was pointed out by Paladino and Garcia [5]. In the case of indigenous children, the mismatch between their culture and the classroom is evident, especially when considering science related subjects. Children from these groups normally learn through observation, a strategy they will carry over into adulthood. The public schools' way of teaching is felt by indigenous children as excessive in terms of verbal communication, whereas they prefer to learn in a more silent way and by observing elders, parents, and siblings.

\section{THE ACTIVITIES}


The GalileoMobile activities that are normally performed in regular schools were developed during the early phases of GalileoMobile's first expedition in 2009 and compiled into a Handbook of Activities (http://www.galileo-mobile.org/galileomobileresources/galileomobile-handbooks). These hands-on activities were chosen from different online sources (e.g. Universe Awareness programme - UNAWE, Galileo Teacher Training Program - GTTP, National Aeronautics and Space Administration - NASA) based on their use of cheap and readily available materials and being interactive. The contents range from topics related to the Solar System, Physics of the Sun, Galaxies, Big Bang and Constellations.

The Handbook activities were then adapted to the GalileoMobile project's cultural and regional particularities as well as translated to the local languages. Over the years, many improvements have been proposed, especially in terms the inclusion of new science teaching methodologies such as inquiry-based learning applied to astronomy. These activities constituted the basis of the work developed by GalileoMobile BraBo's project in 2014 with the Paiter Suruí.

The main goal of the GalileoMobile Constellation Rondônia project 2016 was to expand the knowledge about the ethnoastronomy of the Paiter Suruí. Therefore, special activities were developed to be undertaken in the indigenous schools and communities, considering the particularities of their astronomical knowledge. Therefore, in this project, we gave emphasis to activities such as the night/day sky observation; story telling followed by drawings contemplating both traditional myths related to astronomy narrated by elders as well as modern scientific explanation of phenomena narrated by the astronomers; Lightyear documentary screenings with open air discussions; shadow puppets created and narrated by the Paiter Suruí; cine-club activities with various short animations and a set of conversation on themes proposed by the group.

Our activities used ethnoastronomy as a resource to encourage a discussion in the community about the traditional knowledge related to the sky, especially with the youngsters. Although this kind of approach may represent a novelty for science outreach projects, it is not necessarily the case for science education scholars and teachers that are dealing with indigenous education. For example, Garcia [6] says that ethnoastromy "can provide the indigenous student (and the entire pedagogical team) with a continuity of their culture, helping them to understand and learn a set of descriptions and explanations about astronomy from the perspective of their people". For this author, in the school context, activities that deal with ethnoastronomy may contribute to the dissemination of ethnoastronomic knowledge itself within the communities.

\subsection{Activities details}

In 2014, GalileoMobile members went to Linha 12 region, visiting Sertanista Francisco Meirelles and Paiterey Schools. The team spent four days in the region (from 20-24 ${ }^{\text {th }}$ August 2014) and was comprised of four astronomers and two film-makers.

In 2016, three astronomers and one filmmaker, accompanied by an anthropologist in training who is also an educator, started the GalileoMobile activities once again at Linha 12, working with students of Escola Estadual Indígena de Ensino Fundamental e Médio Sertanista Francisco Meirelles, visited on 1-2 ${ }^{\text {th }}$ of November. On $4-5^{\text {th }}$ November, the team went to Linha 14 territory, working with students of the school Escola Indigena Sertanista José do Carmo Santana and visiting the Museum Paiter A Soe. On 5-6 the team went to Linha 9, where the eldest members of the Paiter Suruí people lived. Because of the short 
time and the importance of talking to the elders, we did not perform activities with the students, only with the community. GalileoMobile also visited a Cultural Centre that opened a few days after our visit. The itinerary followed by GalileoMobile during both BraBo (2014) and Constellation (2016) projects to the region and the activities performed are given in the Table 1.

Table 1. GalileoMobile activities with the Paiter Suruí

\begin{tabular}{|l|l|l|}
\hline \multicolumn{1}{|c|}{ Location - School } & \multicolumn{1}{c|}{ Days } & \multicolumn{1}{c|}{ Activities } \\
\hline $\begin{array}{l}\text { Linha 12, Cacoal - } \\
\text { Francisco Meirelles and Paiterey } \\
\text { Schools }\end{array}$ & 20-24 August 2014 & $\begin{array}{l}\text { Teacher Workshops, Star Party and } \\
\text { Shadow Puppetry }\end{array}$ \\
\hline $\begin{array}{l}\text { Linha 12, Cacoal - } \\
\text { Francisco Meirelles School }\end{array}$ & 1-2 November 2016 & $\begin{array}{l}\text { Cine-club; Light-Year documentary } \\
\text { screening; Story-telling and } \\
\text { drawings; Observation of the Sun; } \\
\text { Talk about the Moon; } \\
\text { Ethnoastronomy research. }\end{array}$ \\
\hline $\begin{array}{l}\text { Linha 14, Cacoal - } \\
\text { Indígena Sertanista José do } \\
\text { Carmo Santana School and } \\
\text { Museum Paiter A Soe }\end{array}$ & 4-5 November 2016 & $\begin{array}{l}\text { Opening talk and drawings; Cine- } \\
\text { club; Observation of the Sun; } \\
\text { Museum visit; Ethnoastronomy } \\
\text { research. }\end{array}$ \\
\hline Linha 9, Cacoal - No school visit & 5-6 November 2016 & $\begin{array}{l}\text { Shadow puppetry; Story-telling; } \\
\text { Ethnoastronomy research. }\end{array}$ \\
\hline
\end{tabular}

Each school received a kit with astronomy-related education and ethnographic research on the Paiter Suruí. Fig. 1 shows two activities at Linha 9 and 14.

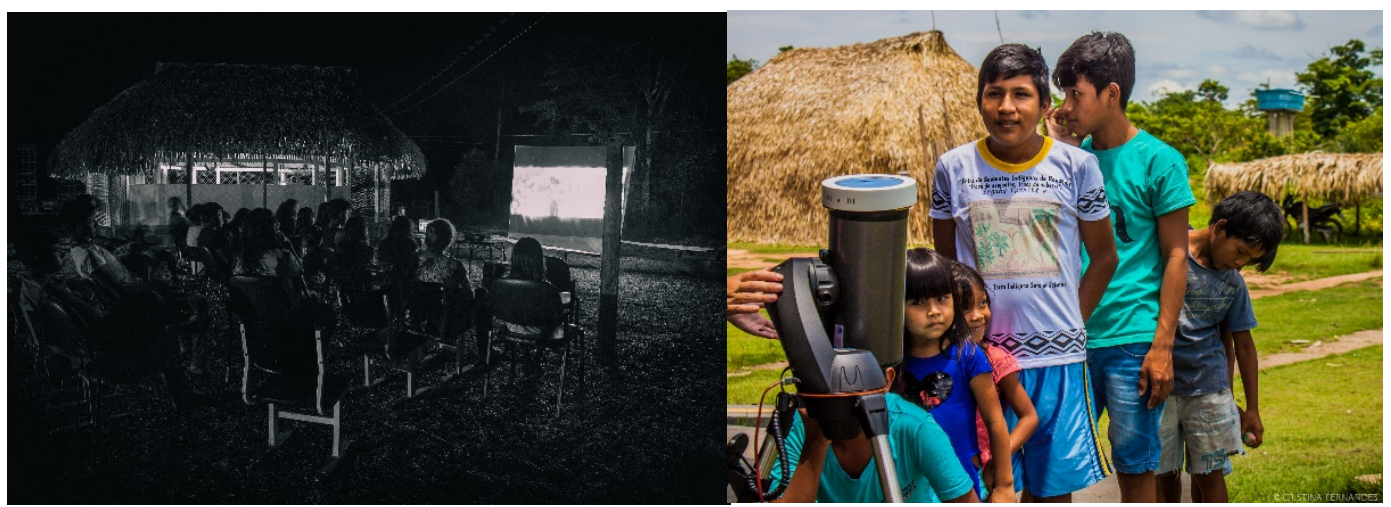

Fig. 1. Light-year exhibition at Linha 12 (left) and observation of the Sun at Linha 14 (right).

\section{DISCUSSIONS AND PRELIMINARY RESULTS}

The Rondônia Constellation expedition made it possible to expand the knowledge about the ethnoastronomy of the Paiter Suruí. Special activities were developed, considering the particularities of the astronomical knowledge of this indigenous group. All activities were developed following the studies presented in Section 3. These activities were an important 
starting point for the understanding of local knowledge and resulted in various forms of recording (audio, video, photographic, paintings and sculptures). All records will be returned to the community, so that the new generations can use them in manufacturing didactic material for their schools and as material for consultation and dissemination of the Paiter Suruí culture.

In addition, the material resulting from the expedition was used for the development of the dissertation degree in anthropology by the member of the expedition in training. The dissertation entitled in Tupi-Mondé as "GÂNI KAPÂN, TXOYKAB EY EITXA ELEWA", meaning that "The Dark Sky is the home of the stars", discusses the actions carried out by the GalileoMobile group, to show how ethnoastronomy is closely linked to the social and cultural organization of the Paiter Suruí.

We conclude this paper by registering a preliminary transcription of the myth related to the Moon. The complete results of the ethnoastronomy of the Paiter Suruí group is presented by [7].

"This story goes back to the ancient times, when all the creatures harmoniously lived on Earth and the gods communicated with the humans through the animals, and the heaven (Gâni), Earth and the stars (Txoykab) were still forming. It all started with a girl in the beginning of her adulthood. Each day, when she went to sleep, she received a visit from a stranger. This man, whose face the darkness blurred, laid with her and left before dawn. He never spoke nor revealed his identity. They only loved each other and nothing more. The girl was very curious to know who her lover was. One day she had an idea. She would prepare an ink made of genipapo to mark the face of her lover. Then, in the light of day, she would discover who the man was. At night, in a moment of distraction, the girl plunged her hand into the ink and stroked the man's face without him noticing. In the next morning the girl asked her mother if she had seen someone with a face painted with genipapo ink. The girl believed that her lover was her maternal uncle, since in the Paiter Surui culture; it is the uncle who marries the niece. But the mother, who already knew about the secret meetings, was desperate. The man was the girl's brother! As punishment for disobeying the marriage law, they were sent far from the village, as far as possible, to another world: the sky, where the stars live. They went up, through a ladder that connected the earth and moon and stayed there, as a penalty for the crime they committed."

\section{References}

[1] P. Faulhaber. "As estrelas eram terrenas: antropologia do clima, da iconografia e das constelações Ticuna”. Rev. Antropol., vol. 47, n. 2 (2004)

[2] B. Wynne. "Elefantes nas salas: onde os públicos encontram a ciência?: Uma resposta a Darrin Durant, Refletindo sobre a expertise: Wynne e a autonomia do público leigo". Rev. Antropolítica, 36 (1), (2014)

[3] B. Midlin. "Nós Paiter: Os Suruí de Rondônia". Petrópolis: Editora Vozes, (1985)

[4] C. Lèvi-Strauss. The Savage Mind (1962)

[5] M. Paladino \& S. M. García. "La escolarización en los pueblos indígenas americanos: impactos y desafios". Quito: Abya-Yala. 429 (2011)

[6] C. S. Garcia. "As coisas do Céu: Etnoastronomia de uma comunidade indígena como subsídio para a proposta de um material paradidático". Rev. Relea, n.21 (2016)

[7] A. P. Germano. GÂNI KAPÂN, TXOYKAB EY EITXA ELEWA. (O Céu Escuro é a

Morada das Estrelas). Monografia de Graduação em Antropologia pela UFF (2017) 